\title{
THE YOUNG KYAI (LORA) AND TRANSFORMATION ON THE PESANTREN IN MADURA
}

\author{
Abd. Muhith ${ }^{1}$, Umiarso El-Rumi ${ }^{2 *}$ \\ ${ }^{1}$ State Islamic Institute Jember, East Java, Indonesia, email: abdmubith.ftik@iain_jember.ac.id \\ ${ }^{2}$ University of Muhammadiyah Malang, East Java, Indonesia, email: umiarso@umm.ac.id \\ *Coressponding Author
}

\begin{abstract}
(c) (i) (2)
C2020 by the authors. Submitted for possible open access publication under the terms and conditions of the Creative Commons Attribution-ShareAlike 4.0 International License-(CC-BY-SA) (https://creativecommons.org/licenses/by-sa/4.0/) doi DOI : http:// dx.doi.org/10.30983/islam realitas.v6i2.3484
\end{abstract}

Submission: 09 September $2020 \quad$ Revised: 02 December $2020 \quad$ Published: 31 December 2020

\begin{abstract}
This research focuses on the leadership of the A'wam Council, group of young religious scholars or kyai (Lora) at the Mambaul Ulum Bata-Bata Pamekasan Madura Islamic Boarding School, in carrying out institutional transformation of the pesantren (traditional Islamic boarding schools). As the protector of religious-culture, Lora not only preserves the various acpects of religion such as marriage and security (by performing the rituals of tablil, or yasinan) but also maintains public morality and good social and political relations in the community. Lora functions as the a protector of culture and religion (amanab or public trust) in order to increase the social capital of the pesantren (enriching social networks). Using the collective leadership theory by O'Neill \& Berinkerhoff and a qualitative approach through observation, interviews, and documentation, this article finds that Lora leadership made use of Islamic values in transforming this institution from a traditional pesantren (salaf) to modern one (khalaf). This process was coupled with the development of an interconnective-integralist paradigm that led to a new pesantren model that not only preserves the traditional methods but also adopted new developments in contemporary thought, namely combining and integrating religious knowledge with general science.
\end{abstract}

Keywords: Young Kyai (Lora); Collective leadership; Pesantren transformation

\begin{abstract}
Abstrak
Riset ini memfokuskan pada dinamika kepemimpinan Dewan A'wam-yang merupakan kumpulan kyai muda (Lora) di Pesantren Mambaul Ulum Bata-Bata Pamekasan Madura-dalam melakukan transfomasi kelembagaan pesantren. Sebagai pelindung budaya-agama, Lora tidak hanya memposisikan diri untuk menjaga berbagai dimensi agama seperti pernikahan dan keselamatan (tablil, atau yasinan), namun juga menjaga moralitas budaya masyarakat serta dinamika sosial politik. Konsistensi dalam peran sebagai pelindung budaya-agama difungsikan oleh Lora untuk menumbubkan modal sosial pesantren (amanah dan jejaring sosial). Dengan menggunakan teori kepemimpinan kolektif oleh O'Neill \& Berinkerhoff dan pendekatan kualitatif melalui observasi, wawancara, dan dokumtasi, artikel ini menemukan bahwa kepemimpinan Lora didasarkan pada nilai-nilai religius Islam di dalam melakukan pengelolaan pesantren bingga mampu bertransformasi dari pesantren tradisional (salaf) ke modern (khalaf). Proses tersebut dirangkai dengan perkembangan paradigma interkonektif-integralis yang berimplikeasi pada model pesantren yang hanya mengajarkan ilmu agama akan diganti dengan nuansa baru, yaitu memadukan dan mengintegrasikan ilmu agama dengan ilmu umum.
\end{abstract}

Kata Kunci: Kyai Muda (Lora); Kepemimpinan kolektif; Transformasi pesantren

\section{Background}

This research elaborates on the pattern of Islamic boarding school (pesantren) leadership in Madura that tends to be centralistic and authoritative with respect to the various

${ }^{1}$ Edi Susanto, 'Kepemimpinan (Kharismatik) Kyai dalam Perspektif Masyarakat Madura', Karsa: Journal of Social and Islamic Culture, 11. 1 (2007), 30-41; Zainal Alim, 'Pergeseran Orientasi Kelembagaan Pesantren di Madura: Perspektif Kiai di Bangkalan', Jurnal Pendidikan Agama Islam, 4. 2 (2016), 249-270; Ali Rahmat \& Fika Fitrotin educational models that is implemented in this institution. ${ }^{1}$ The influence of the chief religious scholar of a pesantren (kyai) is such that it tends to be very strong even outside the bounds of school. $^{2}$ This power will in time be passed on to

Karomah, 'Perilaku Kepemimpinan Kontingensi Kiai dalam Memanajerial Pondok Pesantren al-Ittihad Lembung Timur Lenteng Sumenep', Indonesian Journal of Islamic Education Studies, 2.2 (2019), 133-142.

2 Yanwar Pribadi, 'Religious Networks in Madura: Pesantren, Nahdlatul Ulama, and Kiai as the Core of 
the next generation by hereditary succession, a pattern that Falah has termed as regeneration. ${ }^{3}$ This "biological" regeneration of the kyai is positioned as the crown prince, which in Madurese culture is called Lora. In the context of this paper, this figure will be referred to as the young kyai. Despite the fact that the position of the young kyai in traditional Islamic boarding schools (pesantren salaf) in the Madurese community today is not necessarily as a substitute for the kyai himself, he will eventually acquire the authority of his father in the case of his father's death or in the case of a debilitating excuse (udhur), which makes the kyai unable to perform his regular functions as leader of the pesantren.

Thus, in Mambaul Ulum pesantren, BataBata, the young kyai have the same role as the kyai himself, especially when the kyai have an udbur. Their role is not only to substitute the role of the kyai, but they are also able to play a more active role in pioneering institutional change in the pesantren. Like the elderly kyai in Javanese pesantrens, the active role of the young kyai in Mambaul Ulum Islamic boarding school, BataBata (hereinafter referred to as Pesantren Mambaul Ulum) can foster social networking. In Fadhilah's research, this network covers genealogical, ideological, intellectual, theological, and spiritual networks. ${ }^{4} \mathrm{He}$ is capable of attracting both internal and external networks to encourage the development of the pesantren he leads.

The progressive leadership of the young kyai encourages the institutional development of Pesantren Mambaul Ulum. This Islamic boarding school was founded by Abd Majid as a traditional presantren in 1943. However, since the young kyai are taking part in the current administration of the institution, Pesantren Mambaul Ulum has undergone a significant transformation from the salaf (traditional) pesantren system to a khalaf (modern) system. This has led to the establishment of a diniyah (i.e., modern religious) education institutions and also formal education institutions that combine both religious and general education. This institutional transformation stands at the historical foundation of organizations with extensive social networks such as the Nahdlatul Ulama (NU). This network is primarily ideological. This transformed pesantren is also linked to the theological network of the classical theological schools, especially those of Abu alHasan al-Ash'ari $(260$ H / 873 M - 323 H / 935 M) and Abu al-Mansur al-Maturidi (238 H / 852 $\mathrm{M}-248 \mathrm{H} / 862 \mathrm{M}$ ); one of them is that they believe that the pesantren determines the institutional achievements of the pesantren because human actions are created by themselves. Furthermore, its general intellectual networks are based on the classical period of Islamic history that is now combined with recent developments in contemporary science.

Pesantren Mambaul Ulum has had its ups and downs throughout its hist ${ }^{5}$ ory, from its founding in 1943 until the leadership of Abd Qadir in 1959 (second generation), the leadership of Ahmad Mahfudz until 1986 (third generation), and the leadership of Abd Hamid bin Ahmad Mahfudz Zayyadi (fourth generation). The role of the A'wam-Council is to further develop the institutional management of the pesantren in response to the new
Santri Culture', al-Jami'ab: Journal of Islamic Studies, 51. 1 (2013), 1-32; Abd. A'la, et al., 'Islamism in Madura: From Religious Symbolism to Authoritarianism', Journal of Indonesian Islam, 12. 2 (2018), 159-194; and Yanwar Pribadi, Islam, State and Society in Indonesia: Local Politics in Madura (London: Routledge, 2019), p. 23; Abd Hannan \& Kudrat Abdillah, 'Hegemoni Religio-Kekuasaan dan Transformasi Sosial: Mobilisasi Jaringan Kekuasaan dan Keagamaan Kyai dalam Dinamika Sosio-Kultural Masyarakat Madura', Sosial Budaya, 16. 1 (2019), 9-24.
3 Saiful Falah, 'Model Regenerasi dan Kaderisasi Kepemimpinan Pesantren di Kabupaten Bogor', Ta'dibuna: Jurnal Pendidikan Islam, 8.1 (2019), 1-16.

${ }^{4}$ Amir Fadhilah, 'Struktur dan Pola Kepemimpinan Kyai dalam Pesantren di Jawa', Hunafa: Jurnal Studia Islamika, 8. 1 (2011), 101-120. 5 
challenges of the current generation. The caregiving (kyal) position in a pesantren is a sacred figure who administratively delegates his leadership authority to the A'wam-Council, which acts as the next leadership pesantren. It is common for the A'wam-Council to take strategic steps through a collegial leadership approaches. As discussed by Atiqullah, this model does not negate the authority of the head kyai, which has always been the central figurehead of the pesantren. Rather it places the kyai as caregivers, a position that is institutionalized in the Council of Senior Kyai Scholars (masyayikh). ${ }^{6}$ As Hallinger and Heck show, it is precisely this kind of collective leadership that has an impact on educational institutions' capacity for academic improvement. ${ }^{7}$

Therefore, the leadership of the young kyai (lora) in carrying out the task of developing pesantren institutions must be further investigated. Certainly, the success of the pesantren is highly dependent on the senior kyais leadership style. Alam, for example, argues that the existence and sustainability of Islamic boarding schools are dependent on the kyai as a leader, policy-maker, and the main center of all activities of the institution. ${ }^{8}$ As concluded in Rahayani's research, his role includes the assessment of the human resources available. $\quad$ The studies quoted above conclusively assert that the kyai leadership has a strong influence on the pesantren's institutional movements. Therefore, it is natural, if Hilmy concludes that leadership needs to be at the foundation of the Islamic boarding schools' amid the rapid changes taking place in modern society. ${ }^{10}$ This means that the success of the Islamic boarding school's educational system and institution can depend heavily on the leadership style of the young kyai.

This research focuses on the leadership of the A'wam-Council at the Pesantren Mambaul Ulum in conducting institutional transformation. The analysis empirically driven and is based on the theory of collective leadership initiated by O'neil and Brinkerhoff. ${ }^{11}$ This theory states that in collective leadership there are five basic elements, namely: building a shared vision; wholeness; collective wisdom; acting together (coaxial); and evolutive. Therefore, we chose a qualitative method as our research approach, specifically by conducting case studies. While the data collection techniques used interviews, observation, and documentation, we also conduct data analysis using Miles and Hubermann's interactive analysis. The results of this research analysis are also expected to contribute to the theoretical construction of leadership of the Islamic boarding school institutions (pesantrens) in the future.

The question of the authority of the kyai in Islamic boarding school is an exciting subject of research. One example is Yusuf and Taufiq's study, which focuses on the kyais response to government regulations. This research found that the kyai determined the pesantren's innovative response and development to the challenges it faces. ${ }^{12}$ Wekke et al's research
6 Atiqullah, Varian Kepemimpinan Kolektif Pondok Pesantren di Jawa Timur', Karsa: Journal of Social and Islamic Culture, 20. 1 (2012), 21-42.

${ }^{7}$ Philip Hallinger \& Ronald H. Heck, 'Collaborative Leadership and School Improvement: Understanding the Impact on School Capacity and Student Learning', School Leadership \& Management, 30.2 (2010), 95-110.

8 Naufal Ahmad Rijalul Alam, 'Strengthening Leadership Culture: The Role of Kyai in Indonesia Pesantren', at-Ta'dib: Journal of Pesantren Education, 13. 1 (2018), 5-17.

9 Yayan Rahayani, 'Restructuring and Redesigning The Pesantren Toward an Effective Education
Institution', Tarbiyah: Journal of Education in Muslim Society, 4. 2 (2017), 114-127.

${ }^{10}$ Masdar Hilmy, 'Kepemimpinan Modern Berbasis Karakter Pesantren', Jurnal Pendidikan Agama Islam (Journal of Islamic Education Studies), 7. 2 (2019), 89-106.

11 Cassandra O’Neil \& Monica Brinkerhoff, Five Element of Collective Leadership for Early Childhood Professionals (Yorkton Court: Redleaf Press, 2017), p. 20.

12 Moh. Asror Yusuf \& Ahmad Taufiq, The Dynamic Views of Kiais in Response to the Government Regulations for the Development of Pesantren', QIJIS: Qudus International Journal of Islamic Studies, 8.1 (2020), 132. 
focus on the kyai's leadership style in the traditional (salaf) pesantren; he found that the kyai embodies a charismatic and transformative leadership style that was strongly influenced by the pedagogical tradition and culture of the pesantren. ${ }^{13}$ Solichin's research analyzes the authority of the kyai in the salaf pesantren education system. This research concludes that the kyai determines all the books that are studied by the students (santri). This rule strengthens and perpetuates his leadership in the pesantren. ${ }^{14}$ Alam's study also describes the role of the kyai as a leader in Islamic boarding schools. He stated that the pesantren's existence and sustainability were very dependent on the kyai as leaders, policymakers, and the main center. ${ }^{15}$ A study by Supendi et al explores the role of kyai in the maintaining management the pesantren, concluding that the kyai has a central role in selecting workers and maintaining the values and integrity of the institution. ${ }^{16}$

It appears from a number of these studies that the leadership of kyai is very crucial. However, not all Islamic boarding school have positioned the kyai as the sole leadership position that is capable of bringing about change in the Islamic boarding schools. The collective leadership model is also able to impart unique characteristics to the institutional development of the Islamic boarding school.
Therefore, this research emphasizes the collective leadership role of the kyai. The kyai referred to in this context is the young kyai, commonly known as Lora. Research on collective leadership styles is still relatively small, especially in the context of Islamic boarding schools. This reason is the development of the Islamic boarding schools has been assumed to have a close relationship with a single kyais leadership.

\section{The Leadership of the Young Kyai (Lora) in Pesantren Mambaul Ulum}

It should be admitted that the phenomenon of kyai leadership in the Islamic boarding schools has attracted much attention from scholars-for instance, Rahayu and Faraz's research on women's leadership ${ }^{17}$; Thoyib's research on charismatic leadership in developing a pesantren's vision ${ }^{18}$; Umiarso and Muhith's research on the leadership of kyai in developing a pesantren culture ${ }^{19}$; Anwar-Us's research which unravels the reality of paternalistic and centralistic kyai leadership in running Islamic boarding schools ${ }^{20}$; Umiarso's research which unravels how transformative leadership contributes to the development of Islamic boarding school institutions; ${ }^{21}$ or Hafidh et al's research on how the leadership of kyai leads to the ethical and character formation of the students (santri). ${ }^{22}$ These studies show
${ }^{13}$ Ismail Suardi Wekke, dkk., 'Leadership Typology of Tradisitional Islamic Boarding School in Eastern Indonesia: Learning to Lead from DDI Mangkoso', Inferensi: Jurnal Penelitian Sosial Keagamaan, 12. 2 (2018), 331-348.

${ }^{14}$ Mohammad Muchlis Solichin, 'Interrelation Kiai Authorities, Curriculum and Learning Culture in Pesantren Indonesia', Tarbiya: Journal of Education in Muslim Society, 5.1 (2018), 86-100.

15 Naufal Ahmad Rijalul Alam, Strengthening Leadership Culture: The Role of Kyai in Indonesian Pesantren', At-Ta'dib: Journal of Pesantren Education, 13. 1 (2018), 5-17.

16 Pepen Supendi, dkk., 'Transformational Leadership in Pesantren on as Sa'idah, Al Matuq, and Sunanul Huda Boarding School', Jurnal Pendidikan Islam, 7. 2 (2019), 303-316.

17 Eka Adni Rahayu \& Nahiyah Jaidi Faraz, 'The Transformational Leadership of the Female Leader in
Pesantren', Walisongo: Jurnal Penelitian Sosial Keagamaan, 27. 2 (2019), 299-332.

18 Muhammad Thoyib, 'Charismatic Leader on Developing Visionary Pesantren Bidayatul Hidayah in East Java: Profile and Strategy of Dr. KH. Ahmad Musthofa Kamal's Leadership', Jurnal Pendidikan Islam, 7. 1 (2018), 79-99.

19 Umiarso \& Abd. Muhith, 'Construction Organizational Culture in Gender Pesantren Through Kiai's Transformational Leadership', Akademika: Jurnal Pemikiran Islam, 24. 1 (2019), 67-94.

${ }^{20}$ Kasful Anwar-Us, 'The Leadership of Kyai in Islamic Boarding School: A Study of Islamic Boarding School in Jambi', al-Ta'lim Journal, 22. 1 (2015), 88-95.

21 Umiarso, 'Kepemimpinan Transformasional Profetik dalam Mengembangkan Pesantren di Kabupaten Jember', Akademika: Jurnal Pemikiran Islam, 23. 1 (2018), 87-106.

22 Zaini Hafidh, et al., 'The Role of Kiai Leadership and Character Education: A Pattern of Santri Character 
that that kyai leadership in Islamic boarding schools is essential. Thus, attempts to accelerate the development and transformation of Islamic boarding school institutions are largely determined by the leadership of the kyai.

Likewise, in the Pesantren Mambaul Ulum, the role of the kyai determines the course of the institution. As pointed out in a number of studies, the kyais leadership has an essential position in administration of the institution. Therefore, researchers such as Sukowati et al, ${ }^{23}$ Kingsley, ${ }^{24}$ and $\mathrm{Ahmad}^{25}$ consider that in addition to the role of the kyai - which includes in this context the leadership of the young kyai-no other roles have the same impact on the institutional transformation of the pesantren. The young kyai in Pesantren Mambaul Ulum was, in fact, able to provide a unique contribution in institution's leadership, especially in light of Madurese culture. One can see the uniqueness of this leadership model from its application of democratic, egalitarian, and collective paradigms of leadership. The openness of the pesantren's governance can be realize at all levels, as in the formulation of the vision and tasks of the organization, its goals, curriculum, learning strategies (both modern and traditional), as well as in the procurement of school infrastructure, cleanliness, and order.

This means that the central role of the kyai leadership in Pesantren Mambaul Ulum is vast and deeply rooted. Naturally, people living around Pesantren Mambaul Ulum believe that the young kyai has an essential role in the formation and development of the educational movement in particular and the pesantren institution in general. Even internally, the pesantren itself and the young kyai are open to adopting leadership practices or patterns that are not paternalistic (fatherly). Therefore, Pesantren Mambaul Ulum's leadership often involves parties inside or outside the pesantren, such as religious teachers or the santris guardians. Generally, sometimes dur to its centralized system, the decision-making rocess is very long and inefficient. ${ }^{26}$ The mixed leadership style of the young kyai encourages a shift from a traditional system towards a modern education system. This way pesantren institutions should be able to under a shift from being a tradition institution with tradition management patterns to a modern institution and governance.

These implications are realized collectively based on the togetherness of the young kyai on the A'wam-Council. Togetherness in attaining the same goal is what directs young kyai to work collectively towards institutional success. This is what gives rise to inspiration and commitment on the part of teachers (m. ustadz, f. ustadzah) in the Pesantren Mambaul Ulum. It turns out that the commitment of employees in educational institutions largely determines the success of collective leadership, as indicated by Azeem and Mataruna. ${ }^{27}$ Furthermore, the diversity of talents and skills of the khotdim (i.e., staff, including senior ustadz) has not been diminished from the institutional development of Pesantren Mambaul Ulum. This means the young kyai supports diversity in khotdim reqcruitement, which is in turn stimulates the development of Pesantren Mambaul Ulum into a modern institution. The young kyai in Pesantren Mambaul Ulum divides their
Formation at Asy-Syifa al-Qur'an Islamic Boarding School', Journal of Leadership in Organizations, 1. 2 (2019), 134-145.

23 Praptining Sukowati, et.al., 'Kiai Leadership Model in the Development Strategy of the Participants', International Journal of Recent Technology and Engineering, 8. 2S (2019), 579-586.

${ }^{24}$ Jeremy J. Kingsley, 'Redrawing Lines of Religious Authority in Lombok, Indonesia, Asian Journal of Social Science, 42. 5 (2014), 657-677.
${ }^{25}$ Dihyatun Masqon Ahmad, 'The Dynamics of the Pondok Pesantren: An Islamic Educational Institution in Indonesia', Reaching for the Sky: Religious Education from Christian and Islamic Perspectives, 43 (2012), 63-74.

${ }^{26}$ N.N. (One of the Islamic boarding school's administrators), Interview $\{10$ November 2019$\}$.

27 Muhammad Azeem \& Leonardo Mataruna, 'Identifying Factor Measuring Collective Leadership at Academic Workplaces', International Journal of Educational Management, 33. 6 (2019), 1316-1335. 
authority in the following way. In the A'wamCouncil there are divisions led by one young kyai. This council in structured by their respective assignments and functions so that the authority of each personnel-the young kyai - is standardized and measured.

Sveiby defines collective leadership are joint action in the organization. ${ }^{28}$ The leadership of the young kyai at Pesantren Mambaul Ulum emphasizes moral growth, the development of traditional religious sciences, and collective managerial governance. This joint action is different from traditional pesantren leadership models which only emphasizes morality and sciences dimensions. In this context, the leadership of young kyai can be rationalized as an effort to manage the increasingly complex organizational challenges in the Pesantren Mambaul Ulum institution. These challenges are the pursuit of good governance, academic development, and moral guidance of the pesantren community. Therefore, Anderson states that collective leadership needs to have continuity being creative about the true meaning of success: for whom is it directed and how is it measured ${ }^{29}$ Furthermore, as Bush said, with the increasingly complex dynamics of education, collective leadership is needed, ${ }^{30}$ even though educational institutions have been supported by sophisticated technology. ${ }^{31}$

It is undeniable that in the Islamic boarding schools, the kyai occupies a central position that initiate much of the development, academic activities, and administration of the institution. There is no student (santr) or staff wip can oppose the power of the except for other kyai who have considerably more influence. The leadership of the young kyai of Pesantren
Mambaul Ulum did not orient the institution's managerial style. Instead, they created and built the institutional conditions of an Islamic boarding school, which demanded the staff and leadership to work together continuously. One major problem that emerge from this model is how to identify the objectives of successful management when authority is distributed in a democratic manner to the senior ustady/ustadzah. The presence of the A'wamCouncil at the Pesantren Mambaul Ulum has become the backbone for developing Islamic boarding school institutions.

The young kyai of Pesantren Mambaul Ulum have implemented various strategies that aims to strengthen its management. This includes the arrangement committees' duties and functions and the inclusion of pure science and vocational science in the curriculum. These strategies were actually in the Pesantren Mambaul Ulum, at first, which became the forerunner of the pesantren management tradition. Because this strategy involved the distribution of the elder kyai's, some members of of the pesantren's inner circles consider this development as a diviation from tradition. Others even believed that this model should be prohibited. Nevertheless, other members of the inner circle did not object as they had progressive ideas for the future of the pesantren. A common ground was reached when the leadership of the young kyai was able to bring about a compromise in the institution's management. He placed the elder kyai as the highest symbol of Pesantren Mambaul Ulum's management. At the same time, authority was distributed when it comes to the implementation of policies. ${ }^{32}$
28 Karl-Erik Sveiby, 'Collective Leadership with Power Symmetry: Lesson from Aboriginal Prehistory', Leadership, 7.4 (2011), 385-414.

${ }^{29}$ Michelle Anderson, 'The Struggle for Collective Leadership: Thinking and Practice in a Multi-campus School Setting', Educational Management Administration of Leadership, 40.3 (2012), 328-342.

30 Tony Bush, "Collaborative School Leadership: Can it Co-exist with Solo Leadership in High
Accountability Settings?”, Leadership, 47. 5 (2019), 661662.

31 Trond Eiliv Hauge \& Svein Olan Norene's, 'Collaborative Leadership Development with ICT: Experiences from Three Exemplary Schools', International Journal of Leadership in Education, 18. 3 (2015), 340-364.

${ }^{32}$ N.N. (One of the Islamic boarding school's administrators), Interview $\{10$ November 2019$\}$. 
Thus, the elderly kyai of Pesantren Mambaul Ulum does not govern the Islamic boarding school directly. Instead he is assisted by young kyai. As this goes on, the young kyai (A'wam-Council) coalesced into a solid model of collective leadership to the extent that their position at the pesantren became the foundation and source of cultural and managerial values. This is because they not only play the cultural role-as elderly kyai in generalbut serve in administrative-structural functions. These two roles are based on the distribution of authority, which is characterized by collective strategic decision-making, performance accountability, and committed involvement by all participants.

The young kyai himself believes that the successful transformation of traditional Islamic boarding school institutions into modern Islamic boarding schools can be realized only by fulfilling a number of important conditions. These conditions include a high sense of trust between staff and leadership, effective communication, and collective learning. Fulfilling these conditions would increase a sense of mutual solidarity and car between members of the pesantren and impart a strong moral orientation in life through altruistic acts, commitment to community service, social empathy, and mutual help. According to Yada and Jappinen, these values are a form of prosociality in educational leadership; and it must be instilled in the educational leadership system itself. ${ }^{33}$ Without the collective leadership of the young kyai, Pesantren Mambaul Ulum followed the characteristics and values of the elderly kyai, which focuses more on institutional, managerial, and academic traditions. Therefore, the Pesantren Mambaul Ulum institution before the leadership of the young kyai was in the status quo. Even the its academic tradition was very homogeneous, oriented primarily to the study of Islamic jurisprudence (fiqh). Currently, the subjects studied in Pesantren Mambaul Ulum is very diverse. Since the 2000s, a santri can to study the Qur'an and Hadith; understand and develop science; practice and transform knowledge such as integrating religious and general knowledge; or also vocational knowledge. The pesantren can foster a culture of competitive learning and habituate the students in the contemporary scientific tradition such as in economics, politics, or environmental fiqh.

Therefore, in the A'wam-Council's leadership, the priority is to focus on the institutional development of Pesantren Mambaul Ulum. They are well aware that without the gifts, talents, perspectives, and efforts of many people in Islamic boarding schools themselves, institutional change will be difficult to achieve. ${ }^{34}$ This relational leadership indicator, according to Coleman, can be said to be authentic when it is based on modeling consistent leadership behaviors. ${ }^{35}$ Moreover, the basis of the young kyai's collective leadership lies in efforts in cultivating religious awareness, so that Islamic values will continue to find relevance to the institutional and managerial practices the school. The transformative process of collective leadership values cannot be separated from the following principles that are now enshrined in the pesantren, namely: tarbiyah (education), ubudiyah (religiosity), khuluqiyah (morality), ijtima'iyah (society), and riyadiyah (entrepreneurship).

Looking at the leadership pattern of the A'wam-Council at the Pesantren Mambaul Ulum, it is clear that those who are attempting to advance the Islamic boarding school education system begin by critically evaluating the school's education program. Thus, the
33 Takumi Yada \& Aini-Kristiina Jappinen, 'A Systematic Narrative Review of Prosociality in Educational Leadership', Leadership, 47.6 (2019), 1-21.

${ }^{34}$ N.N. (The management of the Islamic boarding school's program), Interview $\{27$ February 2020$\}$.
35 Andrew Coleman, 'The Significance of Trust in School-based Collaborative Leadership', International Journal of Leadership in Education, 15.1 (2012), 79-106. 
leadership of young kyai can be rationalized as a dimension of Islamic boarding school leadership to charge and perfect the tasks of the elderly (to lighten and refine) kyai on managerial-structural and cultural aspects. The influence of this leadership is not only internal to Islamic boarding school institutions; it also has an impact on the local communities surrounding the school. Naturally, when there is public confidence in the young kyai, they become cultural-religious role models (patron) for the local community also.

As cultural-religious patrons, young kyai do not only position themselves to take care of religious matters such as marriage, individual devotions (through the rituals of tablil, or yasinan). Rather, they also maintain the cultural and moral fabric of society. They also contribute to the socio-plitical life of the community. Because of these diverse roles, the young kyai are able to futher develop and expand the prestige of Pesantren Mambaul Ulum in Madurese society. Currently, the pesantren's alumni are not only active in East Java but are also active in other parts of the Indonesian archipelago. The consistency of the cultural-religious patron is functioned by young kyai to growing up the pesantren's social capital (yaitu trust (from people) and social networks (scientific and funding relations).

\section{The Role of the Young Kyai (Lora) in} Transforming Pesantren Mambaul Ulum

The young kyai at Pesantren Mambaul Ulum have a relatively representative social and institutional role in reviving Islamic boarding school culture through the assistance provided by the Ma'badyah-Council, Madrasiyah-Council, Taudrifiyah-Council, Amnil Amm-Council, and other bureaus of the pesantren. They design the Islamic boarding school's culture into a system that disseminates beliefs, values, and norms. In doing so, they become a normative reference for the Pesantren Mambaul Ulum community. Jappinen and Ciussi's research states that future education needs to encourage dialogue to build shared meaning and exploit a plurality of knowledge. ${ }^{36}$ However, the young kyai who lead the transformation of Pesantren Mambaul Ulum's institution still adhere to the basic principles of Islamic boarding schools, which is based on Islamic religious values and norms. The institutional transformation of this pesantren is very closely linked to the innovative thinking and creativity of the young kyai.

Thus, the Pesantren Mambaul Ulum's education system is very much tied to the presence of the young kyai. The contribution of the young kyai has inspired a line of ustadzwho are also the main management staff of the pesantren-to imitate their leadership patterns and consistency. ${ }^{37}$ Without realizing it, the leadership of the young kyai is more closely related to the management of pesantren institutions rather than the position of authority of the elder kyai. However, the status of the elder kyai as the highest authority in Pesantren Mambaul Ulum was maintained. The elder kyai and young kyai play different roles, but with the same orientation, namely the improvement of the Pesantren Mambaul Ulum as an institution. In the institutional context, the young kyai are positioned as partners of elder kyai whose job is to translate educational authority and pesantren institutions into specific policies.

In conducting institutional transformation and maintaining the existence of Pesantren Mambaul Ulum, the young kyai do so through trust, network, and building shared values with the local community. As a result, in addition to adapting to social transformation, the young kyai continue to oversee the vision of founders of Pesantren Mambaul Ulum. This includes their role as "culture brokers." Therefore, as Machmudi's research argues, the role of the kyai

International Journal of Leadership in Education, 19. 4 (2016), 482-504.

${ }^{37}$ N.N. (The management of the Islamic boarding school's program), Interview $\{27$ February 2020$\}$. 
as a cultural intermediary has not changed since his successors continue to carry out that role. ${ }^{38}$ The path they took was to develop the intellectual values of the founders of Pesantren Mambaul Ulum in the form of books written in Arabic so that their philosophical values remain preserved and enacted. In this context, the young kyai continuously implements various innovations in the teaching of the traditional "yellow" books (kitab Kuning), such as the study of substantive Islamic jurisprudence (fiqh) or also, perform the five daily prayers (Maktuba) in the congregation.

From the various transformative efforts of the A'wam-Council, Pesantren Mambaul Ulum can stand as the central axis of the social, cultural, and religious dynamics of Madurese traditional-agrarian Islamic society. However, the pesantren's transformation continues to develop while preserving its main character, namely as a dakwah (Islamic mission or propagation) institution with a vision to create students (santri) who understand religion (tafaqquh fi al-din), displays noble moral traits, and can live independently. However, in general, the transformation of Islamic boarding school-including Pesantren Mambaul Ulum - cannot be separated from the support of the local community itself and the standard of equality and simplicity amont its students, without distinguishing the status and wealth level of the students' parent. Finally, this transformation is impossible without continuing the important mission of "eliminating ignorance," by means of tafaqquh $f i$ al-din and propagating Islamic teachings. ${ }^{39}$ Moreover, the Madurese are known as militant and consistent Muslims. One example of this is that the Madurese who made the pilgrimage (pilgrimage-migration) came to form a "Madura mafia" in Mecca, as Lucking described in his research. ${ }^{40}$ The characteristics of Pesantren Mambaul Ulum and Madurese militancy have combined to produce a transformation of the pesantren from a traditional Islamic boarding school (salaf) to a modern one (khalaf).

From this cohesiveness, the leadership of the young kyai in Pesantren Mambaul Ulum has a central role in monitoring how their institutional transformation takes place. In this aspect, the young kyai play the role of guardians of the Islamic Boarding School academic tradition and its organizational development. However, the pesantren remains within the basic framework of Islamic boarding schools, which primarily functions as a missionary institution that continuously internalizes Islamic values within the school community and the general public. To support its primary function, Pesantren Mambaul Ulum has three main elements, namely: the A'wam-Council (young kyai) as managers, teachers, as well as role models (uswah) of the Islamic boarding school community; the Islamic boarding school curriculum; and finally religious and educational facilities, such as mosques, boarding halls, and school buldings.

In this position, the young kyai confirmed that Pesantren Mambaul Ulum remains within the founding motive of establishing a missionary institution among the Madurese community. They enact development of the institution by means of adaptive patterns, which in the end, can find compatibility and harmony with the current changes in society. Therefore, the Pesantren Mambaul Ulum institution is not continuously stuck with past models of education and organization. However, as Siroj stated, Islamic boarding schools can integrate their development models with better education models until they become flexible Islamic
38 Yon Machmudi, 'Preserving Kyai Authority in Modern Society', Wacana, 15. 2 (2014), 336-350.

39 Muhammad Hasan, 'Inovasi dan Modernisasi Pendidikan Pondok Pesantren', Karsa: Journal of Social and Islamic Culture, 23. 2 (2015), 295-305.
40 Mirjam Lucking, 'Working in Mecca: How Informal Pilgrimage-Migration from Madura, Indonesia, to Saudi Arabia Challenges State Sovereignty', European Journal of East Asian Studies, 16. 2 (2017), 248-274. 
educational institutions. ${ }^{41}$ Alternatively, as Pribadi writes that Islamic boarding schools are indeed traditionalist, moderate, contributive, and adaptive institutions. ${ }^{42}$ From this process of assimilation or acculturation, the young kyai transformed Pesantren Mambaul Ulum into a strong Islamic boarding school with a modern education system.

The strong resolution to transform Pesantren Mambaul Ulum in a bold and new way has led to a conservative reaction in some management circles of the pesantren. Indeed, some circles experienced both the very traditional method of pesantren management that depended on a single leadership pattern of the elder kyai before the transition to the collective leadership of the young kyai. The conservatism of Pesantren Mambaul Ulum management cannot answer the demands of the changing times; As believed by the pesantren's board. Finally, the single leadership of the elder kyai with charismatic characteristics shifted to the collective leadership pattern of the young kyai. occurs primarily in a paternalistic environment. However, the young kyai have evolved dynamically to impart a more egalitarian, democratic, and familial air to the pesantren environment. Similarly, the attitudes and views of the young kyai who are open can create a space of dialogue between their pesantren and the wider community. In this framework, the transformation of Pesantren Mambaul Ulum takes place reciprocally. On the one hand, it learns and adopts educational modernity, and on the other hand, through its traditional patterns, it inspires modern education. If mapped in a clustered manner, the Pesantren
The collective leadership of the young kyai

Mambaul Ulum transformation can be divided into three aspects, namely: first, the learning method aspect, namely from the sorogan (learning system where the santriadvance one by one to read and describe contents of the book in Arabic in front of a teacher or kyal) and wetonan (bandongan) is a teaching method in which the teacher reads, translates, explains, and reviews the contents of the book in medium Arabic; a group of students listened to him; second, those which deals with the content of academic material, namely from the academic tradition of studying religion to the process of adopting the study of the empirical sciences, humanities and social. This also involves the study of religious texts through the so-called "yellow" classical books-namely books written in the classical period of Islam-and integrating them with contemporary scholarship. And the third, managerial aspects, namely from a single kyai's leadership to the democratization of collective leadership (A'wam-Council).

These three aspects are inseparable from young kyai's leadership. The institutional transformation of Pesantren Mambaul Ulum occurs by a process of modernization through the study of technology and science. Indeed, the challenges of modernization reform had a major impact on traditional religious authority, including the kyais authority in Islamic boarding schools. Feener argued that the impact of modernization can be seen in the various models of religious authority. ${ }^{43}$ That is, the institutional transformation of Islamic boarding schools emerged as a response to the the modernization of the education system in the 19th century. ${ }^{44}$ until the 20th century, there was the "ethical politics" of the colonial nation and

41 Said Agil Siroj, Tasawnf Sebagai Kritike Sosial: Mengedepankan Islam sebagai Inspirasi, Bukan Aspirasi (Bandung: Mizan, 2006), p. 210.

42 Yanwar Pribadi, 'Pesantren Pluralis: Peran Pesantren Ngalah dalam Mengembangkan Nilai-Nilai Pluralisme di Tengah Masyarakat yang Multikultural, by M. Muntahibun Nafis', Journal of the Humanities and Social Science of Southeast Asia, 174. 2-3 (2018), 333-337.
${ }^{43}$ R. Michael Feener, 'Muslim Religious Authority in Modern Asia: Established Patterns and Evolving Profiles', Asian Journal of Social Science, 42. 5 (2014), 501516.

${ }^{44}$ Karen A. Steenbrink, Beberapa Aspek Tentang Islam di Indonesia Abad Ke-19 (Jakarta: Bulan Bintang, 1984), p. 158-159. 
the Islamic reform movement in Indonesia. These two factors led to institutional innovation in Islamic boarding schools by the establishment of a modern religious system, mamely the madrasah. ${ }^{45}$ Even Islamic boarding schools also incorporate the madrasah school system into their environment and institutional traditions.

Nonetheless, the young kyai regards the institutional transformation of the Pesantren Mambaul Ulum not as eliminating the roots of the tradition the founders, who mastered religious knowledge and propagated Islamic religious doctrine in the local communities. Moreover, the Islamic boarding school's transformation is mobilized by a passion to provide educational services that are in line with the needs of today's society. According Tontowi et al., this harmonization contributes to the continuity of Islamic boarding school. ${ }^{46}$ Islamic boarding schools that maintained itself tends to have strong roots in the community. This is partly because the pesantren offers employment to the local community. Pesantren Mambaul Ulum's ability to survive and even grow lies in young kyai's ability to manage the institutions.

The success of the young kyais collective success lies in their leadership of all areas of the Pesantren Mambaul Ulum. The education system that is managed by the Head of the Education of the Ma'badiyah-Council includes the study of the yellow books (Kitab Kuning), Educational Institutions for Teachers (LPTP), and a "Division of Pentashib Baca al-Qur'an" (DPBA) -read; Teachers of Qur'an Reading. The shift in charismatic leadership from the elderly kyai to the A'wam-Council, renders Pesantren Mambaul Ulum's leadership into a very different kind of Islamic boarding school.

45 Mujamil Qomar, Pesantren: Dari Transformasi Metodologi Menuju Demokratisasi Institusi (Jakarta: Erlangga, 2006), p. 90-97.

46 Mahmud Tontowi, et.al., 'Applying the Performance Prism Method to Evaluate Performance of School: A Case Study in Pondok Pesantren Darul Quran
This is a leadership that arises through a spirit of togetherness, such as collective decision making, setting a common vision and tasks collectively, and setting a culture of reciprocal accountability. According to McKergow, this kind of leader is onie who thinks as a "host" (bost leadership). ${ }^{47}$

The attitude of public service that exists in the young kyai's policies based on collaborative relationships is very beneficial for Pesantren Mambaul Ulum. Without prejudice to the authority of the elderly kyai, the young kyai in the A'wam-Council has a significant role in making breakthroughs in Pesantren Mambaul Ulum institutions. ${ }^{48}$ Progressive efforts in pesantren education are continuously carried out to gain public trust through the activities of alumni. This strong bond also encourages the young kyai to play an active role in the local community, such conducting community empowerment training or religious counseling. This community role has had a positive impact on the institutional transformation of the pesantren.

Without the collective leadership role of the young kyai, the institutional transformation of Pesantren Mambaul Ulum would not have been possible. On the other hand, there is the growing self-confidence of the young kyai as the initiator and manager of collective leadership. Moreover, the compliance of members of th pesantren community is based on spiritual values. This means that the existence of spiritual values in educational institutions is recognized by the young kyai themselves as contributing to the pesantren's administrators' performance. The spiritual capital that is firmly attached is oriented to increasing motivation and performance of the Pesantren Mambaul Ulum community.

Mojokerto', Journal of Talent Development and Excellence, 12. 1 (2020), 1884-1893.

${ }^{47}$ Mark McKergow, 'Host Leadership: Towards a New Yet Ancient Metaphor', International Journal of Leadership in Public Services, 5.1 (2009), 19-24.

${ }^{48}$ N.N. (The management of the Islamic boarding school's program), Interview $\{09$ April 2020$\}$. 


\section{Collective-Religious Leadership Pesantren Mambaul Ulum}

Pesantren Mambaul Ulum's shifting leadership has influenced Pesantren Mambaul Ulum's institutional managerial traditions. However, it still maintains its uniqueness as a sub-culture. Wahid claims that this is because of three main elements, namely the pattern of leadership centered in the figure of the kyai lies outside of the leadership of the village administration; its main source of knowledge, i.e., the "yellow" books, has been continually preserved for centuries; and its own value system that is separate from the community in general. ${ }^{49}$ Pesantren Mambaul Ulum's transformation process has produced very different model from the national education system such as school sor universities. Even though the pesantren is a formal education institution, it is still based on its own institutions, including its own educational system and the values that underly it. Therefore, Islamic religious values are the primary foundation for managing the Pesantren Mambaul Ulum education system and institutions. Automatically, the leadership style of the young kyai also promotes Islamic values as the management principles.

Interestingly the leadership of these young kyai, besides transforming the organizational and leadership style of the pesantren, is also seen as bringing about divine blessings and wisdom in the santri's education. This religious impact is based on the attitude of the young kyai who relied on internalized Islamic values. Their actions must reflect prophetic values such as humanism, liberation, and transcendence. The actions of the young kyai lead to the humanity values of Pesantren Mambaul Ulum. Therefore, the young kyai continue to struggle and sacrifice themselves to break through the status quo in order to successfully transform Pesantren Mambaul Ulum into a better institution. The foundation is Islamic teachings that are translated into concrete actions. Indeed, the substance of the normative message of management and organization in Islam is primarily focused on humanity ${ }^{50}$; thus, the spirituality enlightenment of humanity is integrated into the leadership attitudes of the young kyai.

The teachers (ustadz) also consider that the young kyai are collectively abiding by authoritative sources, namely the Qur'an, the Hadith, and also the consensus (ijma) of the scholars. This can be seen in action when decisions are to be made: the young kyai prioritizes deliberation (syuro) because it is recorded explicitly in the Qur'an. These attitudes have indeed become habits of the young kyai to such an extent that their leadership style (A'wam-Council) is firmly tied to the spirit of religious morality. The young kyai himself admits that it will have been difficult to achieve good results without religious values. Because it can position as a normative value that is "passed over" -read; beyond- of the successful embodiment of Pesantren Mambaul Ulum institutional management.

Based on Islamic religious values, the young kyai cultivate noble moral values that lead to an increase in Pesantren Mambaul Ulum's spiritual morality. Such institutional and social innovation is in line with Klaus and Fernando's research findings that the orientation of spiritual leadership is to realize social innovation. $^{51}$ According to Wahid and Mustamil, this orientation can also influence human values and make the life of the

Management and Organization, Abbas J. Ali', Review in Religion and Theology, 13. 3 (2006), 330-333.

51 Lauren Klaus \& Mario Fernando, 'Enacting Spiritual Leadership in Business Through EgoTranscendence', Leadership \& Organization Development Journal, 37.1 (2016), 71-92. 
organization meaningful. ${ }^{52}$ The style of collective leadership of the young kyai combined with Islam's religious values has triggered a dynamic and transformative movement that is institutionally implemented in the socio-religious spirit. Thus Pesantren Mambaul Ulum also develops because of its foremost function as a missionary institution.

Therefore, the young kyai through collective leadership try to continue to develop the competencies of Pesantren Mambaul Ulum citizens. Furthermore, on the other hand, they increase their awareness with ideals and moral values such as freedom, justice, equality, peace, and humanity. However, because the young kyai are not "keepers" of a system that can run monotonously at any time, they often challenge the prevailing mindset. They believe that if the current policies of traditional Islamic boarding schools end up preventing progressive thought and action, they would take steps that most kyai would never take. Thus, the young kyai in the A'wam-Council believe in the institutional development of Islamic boarding schools as a central strategy of the leadership. Indeed, the transformation of Pesantren Mambaul Ulum was carried out in a structured, progressive, and inclusive environment. Gotsis and Grimani's research explains that an inclusive environment clad in spiritual values mediates leadership's relationship with the organizational climate becoming more inclusive. ${ }^{53}$ Even Mahipalan and Sheena's research finds a significant relationship between spirituality, happiness, and gratitude at the workplace. ${ }^{54}$

The combination of the leadership of the young kyai with the values of Islamic spirituality allows the members of the pesantren community to attain a high level of potential. The implication is that the value of rabbaniyah (i.e., the values of sincerity, resignation, patience, gratitude as manifestations of the value of obedience to God) and the value of insaniyyah (i.e., the values of simplicity, togetherness, and patience as manifestations of social obedience) has penegrated the managerial institutions of Pesantren Mambaul Ulum. This serves as an anchor for the development of humanist-religious-based education in Islamic boarding schools. The balance between humanity and divinity, and between personal and social piety frames the Pesantren Mambaul Ulum education. This balance also shows how the collective leadership of the A'wam-Council focuses on developing human resources through education. Thus, the religious dimension of Islam can have a positive impact on the A'wam-Council itself and the environment. This condition also refutes the results of Schmidt's et al's research, which states that religious activities open up opportunities for someone to experience religious delusions. ${ }^{55}$

Performance that oriented to worldly and other-worldly aims is combined powerfully within the framework of the young kyais leadership. Researchers see that the leadership style of the young kyai does not give up their cultural authority as Madurese and Muslim people. Therefore, the assimilation of cultural and Islamic values is bound within the framework of educational institutions. On the other hand, assimilation creates an agreement within Pesantren Mambaul Ulum that must be accepted as a measure for daily behavior. It is common to hold educational management activities as being equivalent in value to religious

54 Manju Mahipalan \& Sheena, 'Workplace Spirituality and Subjective Happiness Among High School Teachers: Gratitude As A Moderator', Explore, 15. 2 (2019), 107-114.

${ }^{55}$ Heike Anderson-Schmidt, et.al., 'The Influence of Religious Activity and Polygenic Schizophrenia Risk and Religious Delusions in Schizophrenia', Schizophrenia Research, 210 (2019), 255-261. 
practices or even rituals. Thus, they argue that performance in institutional management is the same as worshipping God.

Therefore, the young kyai-through collective leadership-do not only work to realize Pesantren Mambaul Ulum's institutional transformation goals. They also develop the academic potential and spirituality of their students These two dimensions (institutional and religious) are integrated into the leadership style of the young kyai. This balance in turn massively influences the institutional, managerial, and human resource potentials of the pesantren. Having rational awareness (khalifabtullab) and spiritual awareness (Abdullab) of God-which is piety (taqwa), having noble character (al-akblaq al-karim), and behaving effectively and efficiently (al-itgan) is the ideal behavior of young kyai leadership. In Salleh's research it is said that such behavior is an indicator of the Islamic leadership model. ${ }^{56}$ Marbun also argues that this behavior is a requirement of Islamic leadership. ${ }^{57}$

It is said that leadership behavior is a stronger predictor of personal attitudes and satisfaction, as found in Alhouti and D'Souza's research. ${ }^{58}$ Collective leadership behavior can also inspire a vision of leadership; enhance credibility and continuity, and enhance moral values as well as reduce ethical problems; these implications are stated in the research conclusions of Ramachandran et al. ${ }^{59}$ Therefore, the behavior or leadership style of the young kyai subverts conventional barriers of elderly kyai leadership patterns. This shifting of the paternalistic-charismatic patterns of

${ }^{56}$ Mohamad Johdi Salleh, 'Educational Leadership Model: An Islamic Perspective', al-Shajarah: Journal of the International Institute of Islamic Thought and Civilization (ISTAC) Special Issue: Education (2018), 49-70.

57 Dahlena Sari Marbun, 'Attributions and Requirements of Islamic Leadership', Management Research Review, 36.4 (2013), 379-387.

58 Sarah Alhouti \& Giles D'Souza, 'Benefits of Corporate Society Responsibility', Journal of Consumer Marketing, 35.3 (2018), 277-286.

59 Sharmila Devi Ramachandran, et.al., 'Effectiveness of the Use of Spiritual Intelligence in leadership to the style of collective leadership is based on religious values. It carries out managerial transformation motivated by Islamic missionary zeal towards professionalmanagerial model. It also breaks down the dichotomic academic paradigm while developing the integrative-interconnected scientific paradigm.

These leadership styles are referred to by the present authors as collective-religious leadership. This kind of leadership binds leaders to the dimension of revelation based on divine awareness. In this way their behavior in managing educational institutions is always in keeping with religious values. The leaders themselves are very strong in their vision of humanity and divinity. This is represented in the characteristic attitudes of khalifatullah and Abdullah. Because they have high responsibility, they can influence the affective commitment of employees $^{60}$ and position themselves as an integrator in their organization. ${ }^{61}$

We saw that the strategies embraced by the young kyai are not separated, but instead are integrated into a collective orientation for all Pesantren Mambaul Ulum members. The empowerment efforts are carried out collectively and collegially by the A'wamCouncil by uniting the pesantren's vision and institutional goals. Finally, the goal of developing and improving the quality of pesantren education can realize based on this collective leadership pattern. On the other hand, a unified constellation of spiritual values can be internalize within the members of the pesantren's community. As recognized by the

Women Academic Leadership Practice', International Journal of Educational Management, 31.2 (2017), 160-178.

60 Amlan Haque, et.al, 'Responsible Leadership, Affective Commitment, and Intention to Quit: An Individual-Level Analysis', Leadership \& Organizational Development Journal, 40. 1 (2019), 45-64.

${ }^{61}$ David A. Waldman, et.al., 'Defining the Socially Responsible Leader: Revisiting Issues in Responsible Leadership', Journal of Leadership \& Organizational Studies, 27. 1 (2019), 5-20. 
A'wam-Council itself, this work was arduous and required a relatively long time. Nevertheless, the results are nothing less than positive institutional transformation in various aspects, including in academics and others areas, such as aspects of educational and institutional governance.

\section{Conclusion}

The institutional transformation of the Islamic boarding school and its education system is very much colored by the character of the leadership. The young kyai-through collective leadership that is wrapped in Islamic values-can encourage the institutional transformation of Islamic boarding schools. The process is linked to the development of the interconnective-integralists paradigm. Thus the school engages in a diversity of academic subjects. The implication is that Islamic boarding schools that only teach the religious sciences will be replaced one that is more diverse academically, which is to combine and integrate the religious sciences with the general sciences.

Through the leadership of the young kyai, a dual role is created in the kyai themselves, namely, the cultural role and the administrativestructural role. The role of the kyai is, operationally, supporting the democratization of the relationship between the kyai and the Islamic boarding school community. Therefore, the leadership of the young kyai is focused on increasing the dynamic growth of Islamic boarding schools to form more complex institutions and integrative pedagogy. Without the innovative and progressive young kyais leadership, it would be very difficult to oversee the institutional and scientific transformation of Islamic boarding schools. Indeed, the progress of this transformation lies in the leadership dimension that governs it. If the kyais leadership is more open, the school management will also be more open, and vice versa.

\section{References}

\section{Books}

Ali, Abbas J., Islamic Perspective on Management and Organization (Massachusetts: Edward Elgar Publishing, 2005)

O’Neil, Cassandra \& Monica Brinkerhoff, Five Element of Collective Leadership for Early Childhood Professionals (Yorkton Court: Redleaf Press, 2017)

Pribadi, Yanwar, Islam, State and Society in Indonesia: Local Politics in Madura (London: Routledge, 2019)

Qomar, Mujamil, Pesantren: dari Transformasi Metodologi Menuju Demokratisasi Institusi (Jakarta: Erlangga, 2006)

Siroj, Said Agil, Tasawnf Sebagai Kritik Sosial: Mengedepankan Islam sebagai Inspirasi, Bukan Aspirasi (Bandung: Mizan, 2006).

Steenbrink, Karen A., Beberapa Aspek Tentang Islam di Indonesia Abad Ke-19 (Jakarta: Bulan Bintang, 1984)

Wahid, Abdurrahman, Islam Kosmopolitan: NilaiNilai Indonesia \& Transformasi Kebudayaan (Jakarta: The Wahid Institut, 2007)

\section{Journals}

A'la, Abd., et al., 'Islamism in Madura: From Religious Symbolism to Authoritarianism', Journal of Indonesian Islam, 12. 2 (2018), 159-194

Ahmad, Dihyatun Masqon, 'The Dynamics of the Pondok Pesantren: An Islamic Educational Institution in Indonesia', Reaching for the Sky: Religious Education from Christian and Islamic Perspectives, 43 (2012), 63-74

Alam, Naufal Ahmad Rijalul, 'Strengthening Leadership Culture: The Role of Kyai in Indonesia Pesantren', at-Ta'dib: Journal of Pesantren Education, 13. 1 (2018), 5-17

Alam, Naufal Ahmad Rijalul, 'Strengthening Leadership Culture: The Role of Kyai in Indonesian Pesantren', At-Ta'dib: Journal of Pesantren Education, 13. 1 (2018), 5-17

Alhouti, Sarah \& Giles D'Souza, 'Benefits of Corporate Society Responsibility', Journal of Consumer Marketing, 35. 3 (2018), 277-286 
Alim, Zainal, 'Pergeseran Orientasi Kelembagaan Pesantren di Madura: Perspektif Kiai di Bangkalan', Jurnal Pendidikan Agama Islam, 4. 2 (2016), 249270

Anderson, Michelle, 'The Struggle for Collective Leadership: Thinking and Practice in a Multi-campus School Setting', Educational Management Administration \& Leadership, 40.3 (2012), 328-342

Anderson-Schmidt, Heike, et.al., 'The Influence of Religious Activity and Polygenic Schizophrenia Risk and Religious Delusions in Schizophrenia', Schizophrenia Research, 210 (2019), 255261

Anwar-Us, Kasful, 'The Leadership of Kyai in Islamic Boarding School: A Study of Islamic Boarding School in Jambi', alTa'lim Journal, 22. 1 (2015), 88-95

Atiqullah, 'Varian Kepemimpinan Kolektif Pondok Pesantren di Jawa Timur', Karsa: Journal of Social and Islamic Culture, 20.1 (2012), 21-42

Azeem, Muhammad \& Leonardo Mataruna, 'Identifying Factor Measuring Collective Leadership at Academic Workplaces', International Journal of Educational Management, 33. 6 (2019), 1316-1335

Bush, Tony, 'Collaborative School Leadership: Can it Co-exist with Solo Leadership in High Accountability Settings?', Leadership, 47.5 (2019), 661-662

Coleman, Andrew, 'The Significance of Trust in School-based Collaborative Leadership', International Journal of Leadership in Education, 15. 1 (2012), 79106

Fadhilah, Amir, 'Struktur dan Pola Kepemimpinan Kyai dalam Pesantren di Jawa', Hunafa: Jurnal Studia Islamika, 8. 1 (2011), 101-120

Falah, Saiful, 'Model Regenerasi dan Kaderisasi Kepemimpinan Pesantren di Kabupaten Bogor', Ta'dibuna: Jurnal Pendidikan Islam, 8.1 (2019), 1-16

Feener, R. Michael, 'Muslim Religious Authority in Modern Asia: Established
Patterns and Evolving Profiles', Asian Journal of Social Science, 42.5 (2014), 501 516

Gotsis, George \& Katerina Grimani, 'The Role of Spiritual Leadership in Fostering Inclusive Workplaces', Personnel Review, 46. 5 (2017), 908-935

Hafidh, Zaini, et al., 'The Role of Kiai Leadership and Character Education: A Pattern of Santri Character Formation at Asy-Syifa al-Qur'an Islamic Boarding School', Journal of Leadership in Organizations, 1.2 (2019), 134-145

Hallinger, Philip \& Ronald H. Heck, 'Collaborative Leadership and School Improvement: Understanding the Impact on School Capacity and Student Learning, School Leadership \& Management, 30.2 (2010), 95-110

Hannan, Abd \& Kudrat Abdillah, 'Hegemoni Religio-Kekuasaan dan Transformasi Sosial: Mobilisasi Jaringan Kekuasaan dan Keagamaan Kyai dalam Dinamika Sosio-Kultural Masyarakat Madura', Sosial Budaya, 16.1 (2019), 9-24

Haque, Amlan, et.al, 'Responsible Leadership, Affective Commitment, and Intention to Quit: An Individual-Level Analysis', Leadership \& Organizational Development Journal, 40.1 (2019), 45-64

Hasan, Muhammad, 'Inovasi dan Modernisasi Pendidikan Pondok Pesantren', Karsa: Journal of Social and Islamic Culture, 23. 2 (2015), 295-305

Hauge, Trond Eiliv \& Svein Olan Norene's, 'Collaborative Leadership Development with ICT: Experiences from Three Exemplary Schools', International Journal of Leadership in Education, 18. 3 (2015), 340-364

Hilmy, Masdar, 'Kepemimpinan Modern Berbasis Karakter Pesantren', Jurnal Pendidikan Agama Islam (Journal of Islamic Education Studies), 7. 2 (2019), 89-106

Jappinen, Aini-Kristiina \& Melanie Ciussi, 'Indicators of Improved Learning Contexts: a Collaborative Perspective on Educational Leadership', International Journal of Leadership in Education, 19. 4 (2016), 482-504 
Kingsley, Jeremy J., 'Redrawing Lines of Religious Authority in Lombok, Indonesia, Asian Journal of Social Science, 42. 5 (2014), 657-677

Klaus, Lauren \& Mario Fernando, 'Enacting Spiritual Leadership in Business Through Ego-Transcendence', Leadership \& Organization Development Journal, 37.1 (2016), 71-92

Lucking, Mirjam, 'Working in Mecca: How Informal Pilgrimage-Migration from Madura, Indonesia, to Saudi Arabia Challenges State Sovereignty', European Journal of East Asian Studies, 16. 2 (2017), 248-274

Machmudi, Yon, 'Preserving Kyai Authority in Modern Society', Wacana, 15. 2 (2014), 336-350

Mahipalan, Manju \& Sheena, 'Workplace Spirituality and Subjective Happiness Among High School Teachers: Gratitude As A Moderator', Explore, 15. 2 (2019), 107-114

Marbun, Dahlena Sari, 'Attributions and Requirements of Islamic Leadership', Management Research Review, 36.4 (2013), 379-387

McKergow, Mark, 'Host Leadership: Towards a New Yet Ancient Metaphor', International Journal of Leadership in Public Services, 5.1 (2009), 19-24

Pribadi, Yanwar, 'Pesantren Pluralis: Peran Pesantren Ngalah dalam Mengembangkan Nilai-Nilai Pluralisme di Tengah Masyarakat yang Multikultural, by M. Muntahibun Nafis', Journal of the Humanities and Social Science of Southeast Asia, 174. 2-3 (2018), 333337

Pribadi, Yanwar, 'Religious Networks in Madura: Pesantren, Nahdlatul Ulama, and Kiai as the Core of Santri Culture', al-Jami'ab: Journal of Islamic Studies, 51. 1 (2013), 1-32

Rahayani, Yayan, 'Restructuring and Redesigning The Pesantren Toward an Effective Education Institution', Tarbiyah: Journal of Education in Muslim Society, 4. 2 (2017), 114-127
Rahayu, Eka Adni \& Nahiyah Jaidi Faraz, 'The Transformational Leadership of The Female Leader in Pesantren', Walisongo: Jurnal Penelitian Sosial Keagamaan, 27. 2 (2019), 299-332

Rahmat, Ali \& Fika Fitrotin Karomah, 'Perilaku Kepemimpinan Kontingensi Kiai dalam Memanajerial Pondok Pesantren alIttihad Lembung Timur Lenteng Sumenep', Indonesian Journal of Islamic Education Studies, 2, 2 (2019), 133-142

Ramachandaran, Sharmila Devi, et.al., 'Effectiveness of the Use of Spiritual Intelligence in Women Academic Leadership Practice', International Journal of Educational Management, 31. 2 (2017), 160-178

Salleh, Mohamad Johdi, 'Educational Leadership Model: An Islamic Perspective', al-Shajarah: Journal of the International Institute of Islamic Thought and Civilization (ISTAC) Special Issue: Education (2018), 49-70

Solichin, Mohammad Muchlis, 'Interrelation Kiai Authorities, Curriculum and Learning Culture in Pesantren Indonesia', Tarbiya: Journal of Education in Muslim Society, 5.1 (2018), 86-100

Sukowati, Praptining, et.al., 'Kiai Leadership Model in the Development Strategy of the Participants', International Journal of Recent Technology and Engineering, 8. 2S (2019), 579-586

Supendi, Pepen, et.al., 'Transformational Leadership in Pesantren on as-Sa'idah, al-Matuq, and Sunanul Huda Booarding School', Jurnal Pendidikan Islam, 7. 2 (2018), 303-316

Susanto, Edi, 'Kepemimpinan (Kharismatik) Kyai dalam Perspektif Masyarakat Madura', Karsa: Journal of Social and Islamic Culture, 11.1 (2007), 30-41

Sveiby, Karl-Erik, 'Collective Leadership with Power Symmetry: Lesson from Aboriginal Prehistory', Leadership, 7. 4 (2011), 385-414

Thoyib, Muhammad, 'Charismatic Leader on Developing Visionary Pesantren Bidayatul Hidayah in East Java: Profile and Strategy of Dr. KH. Ahmad 
Musthofa Kamal's Leadership', Jurnal Pendidikan Islam, 7. 1 (2018), 79-99

Tontowi, Mahmud, et.al., 'Applying the Performance Prism Method to Evaluate Performance of School: A Case Study in Pondok Pesantren Darul Quran Mojokerto', Journal of Talent Development and Excellence, 12.1 (2020), 1884-1893

Umiarso \& Abd. Muhith, 'Construction Organizational Culture in Gender Pesantren Through Kiai's Transformational Leadership', Akademika: Jurnal Pemikiran Islam, 24. 1 (2019), 67-94

Umiarso, 'Kepemimpinan Transformasional Profetik dalam Mengembangkan Pesantren di Kabupaten Jember', Akademika: Jurnal Pemikiran Islam, 23. 1 (2018), 87-106

Wahid, Nur Kamariah Abdul \& Norizah Mohd. Mustamil, 'Ways to Maximize the Triple Bottom Line of the Telecommunication Industry in Malaysia: The Potentials of Spiritual Well-Being through Spiritual Leadership', Journal of Organizational Change Management, 30. 2 (2017), 263-280

Venten, Gerald, 'Islamic Perspectives on Management and Organization, Abbas J. Ali', Review in Religion and Theology, 13. 3 (2006), 330-333
Waldman, David A., et.al., 'Defining the Socially Responsible Leader: Revisiting Issues in Responsible Leadership', Journal of Leadership \& Organizational Studies, 27.1 (2019), 5-20

Wekke, Ismail Suardi, dkk., 'Leadership Typology of Tradisitional Islamic Boarding School in Eastern Indonesia: Learning to Lead from DDI Mangkoso', Inferensi: Jurnal Penelitian Sosial Keagamaan, 12.2 (2018), 331-348

Yada, Takumi \& Aini-Kristiina Jappinen, 'A Systematic Narrative Review of Prosociality in Educational Leadership', Leadership, 47. 6 (2019), 1-21

Yusuf, Moh. Asror \& Ahmad Taufiq, The Dynamic Views of Kiais in Response to the Government Regulations for the Development of Pesantren', QIJIS: Qudus International Journal of Islamic Studies, 8.1 (2020), 1-32

\section{Interviews}

N.N. (The management of the Islamic boarding school's program), Interview \{ 09 April $2020\}$

N.N. (The management of the Islamic boarding school's program), Interview $\{27$ February 2020$\}$

N.N. (One of the Islamic boarding school's administrators), Interview $\{10$ November 2019\} 